\title{
Beach Tourism Development Strategy in Coastal Area District Tete Bone, South Sulawesi,
} Indonesia

\author{
Ida Rachmaniar Ramli ${ }^{1}$, Ahmad Bahar, Wasir Samad ${ }^{2}$
}

\author{
${ }^{1}$ Integrated Coastal Resources Management Postgraduate Program, Faculty of Marine Science and Fisheries, \\ Hasanuddin University, Makassar-90245 \\ ${ }^{2}$ Department of Marine Science, Faculty of Marine Science and Fisheries, University of Hasanuddin, Makassar-90245 \\ *Email: Idarachmaniarramli@gmail.com
}

\begin{abstract}
The aim of this study was to determine the potential for coastal tourism and Tete Beach tourism development strategy. This research was conducted in August 2019. The collection of data such as water quality, the feasibility of coastal tourism, and interviews. Data analysis using Travel Suitability Index (IKW). Zone Capability (DDK) and the Strengths, Weaknesses, Opportunities, Threats (SWOT). Results of the research suggest that the potential of the Tete Beach Tourism relatively accordance withthe number of visitors to $\pm 128 /$ day cooperation between local communities, the government and the Indonesian National Armed Forces (TNI) is an author suggested a strategy for the development of nautical tourism in Tete Beach.
\end{abstract}

Keywords-Beach Tourism, Coastal Area, DDK.

\section{INTRODUCTION}

Tourist activity has become one of the attractions most in demand by foreign and domestic society. It can be seen from the number of foreign tourists throughout the month of February 2018 amounted to 1.20 million, then increased to 1.27 million people throughout the month of February 2019 and domestic tourists to visit in December 2018 reached 1.100 .67 people and increased to $1,158.162$ people in January 2019 (central statistical agency, 2019). This is because the activities have a wide range of tourist attractions appeal, three of them, namely nature such as flora and fauna, has a characteristic of an ecosystem, the unique natureand cultivation of natural resources (fields, plantations, livestock, and fisheries). Social tourism in the form of traditional culture, legacy history, arts and crafts and attractions of special interest.

One of the many attractions of interest in Indonesia in the form of nature, with the type of marine tourism, this is because Indonesia is a country that has a potential range of submarine and terrestrial (beach) which can be utilized, as well as the richness and density of coral reefs located on Pulau Pisang (Lazuardi, et al., 2013), the abundance of fish species in the National Park Publications (Sulisyati, et al., 2016) contained Turtle Conservation in the village Lamanggo (Buangsampuhi, et al.,2019)as well as the beauty of the topography in the form of cliffs dotted coral reefs Bodies Gantarang (Sani and Mahadjir, 2019), in addition to the beauty beneath the sea, land (the beach)
Indonesia is quite awesome with the panoramic beauty of the beach, located in Watu Frog (Vitello, 2018), the beauty of the sunset and sunrise at the beach Menganti, Kebumen (Febriansyah and Alfiano, 2018).

With a wealth of potential that is quite interesting, making tourist areas in Indonesia as a field of local revenue due to tourist traffic which continues to grow each year (central statistical agency, 2019) following the tourist sites that are frequently visited by tourists according to Marine and Fisheries Ministry that is, Senggigi Beach, on the island of Lombok offers Attraction destinations white sand, snorkeling, and sunbathing and sunset views. Pangandaran island located in Java Island offers attractions sunrise and sunset. Kuta Beach in Bali, providing attractions such as sunset and waves. Parangitis beach located in Yogyakarta, this island presents attractions such as the myth that embodies trine Parangitis Beach (Volcanos, Kraton, Yogyakarta, and Parangitis). Bunaken in Manado bay beaches offers travel objects offered in the form of waves, Attraction steep cliffs, and diving. Raja Ampat beach Attraction providing diving, with the amount of marine life spread in Indonesia (Marine and Fisheries Ministry, 2018).

Some of the tourist sites of the beach is a tourist destination visited by many tourists with characteristic tourist attraction each, this is because characteristic of a tourist area can become Pull-in itself for tourists, as well as characteristic of Tete be tombolo, a natural phenomenon of 
tombolo this is only found on some beaches only, so this may be the main attraction for a tourist area, not only is it in Tete there are also several attractions other like panorama waves, white sand along the coastline, and expanse of mountains who are on the edge and the middle of the sea (Muh.Yahya, 2015).However, the number of attractions found on the Tete Beach does not make Tete Beach as one of the tourist destinations that are much in demand by tourists, this is likely due to the lack of development of several attractions contained in the Tete
Beach, so that researchers are interested in conducting research on development strategies marine tourism area on the Tete Beach

\section{RESEARCH METHOD}

\subsection{Time and Location Research}

The study was conducted in Tete, District Tonra Bone regency. Parameter measurements performed at 3 points with a distance of $\pm 100 \mathrm{~m}$ station Figure 1)

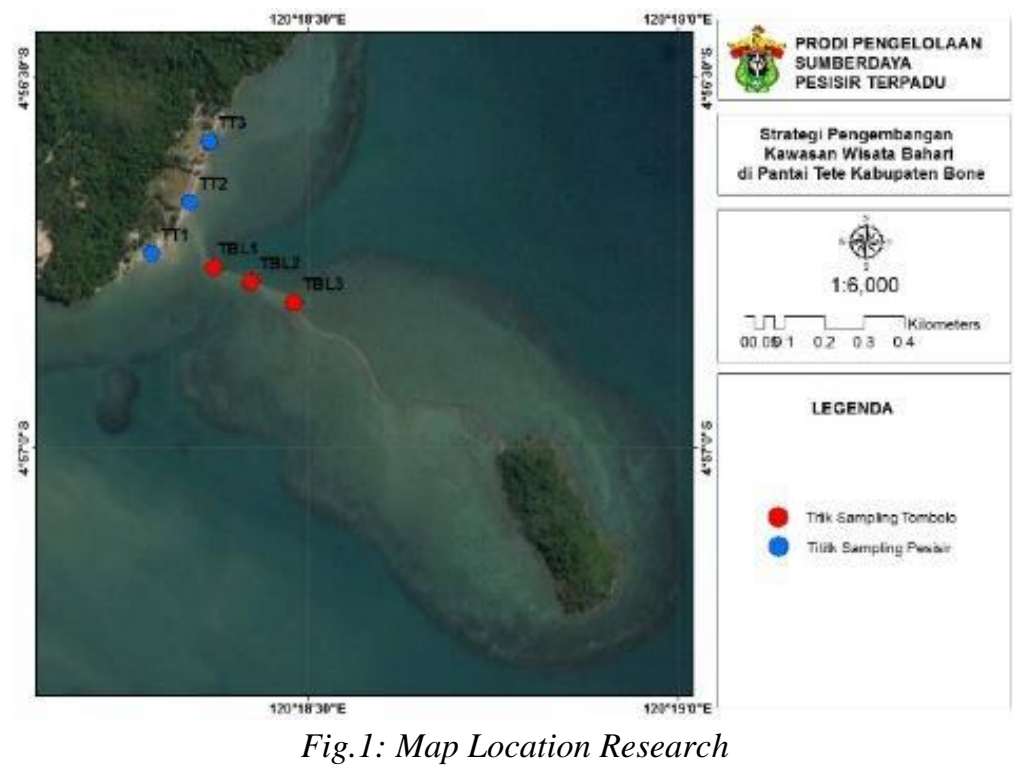

\subsection{Methods and Data Analysis}

\subsubsection{Data Collection Methods}

Data were collected in the form of primary data and secondary data. Primary data includes data obtained directly through field observation techniques, survey and interview techniques. Then the secondary data obtained in agency-related agencies nautical tourism development strategy in Tete Beach. Primary and secondary data will be used to determine the priority of the development of alternative strategies most appropriately carried out, using SWOT analysis.

\subsubsection{Data Analysis}

\subsubsection{Analysis of Water Quality Parameters}

Analysis of water quality parameters is done in situ and ex-situ (laboratory). Eligibility Criteria valuation based on the Ministry of Environment No.51 of 2004 (Table 2)

Table 2 Criteria Parameter Water Quality Standards

\begin{tabular}{l|l|c|c}
\hline \multicolumn{1}{c|}{ No } & \multicolumn{1}{|c}{ Parameter } & Unit & BIMutu \\
\hline \multicolumn{1}{c}{ Physics } & m & $>\mathbf{3}$ \\
\hline $\mathbf{1}$ & Brightness & - & Notsmelling \\
\hline $\mathbf{2}$ & Stink & - & Nothing $\left.^{\mathbf{4}} \mathbf{4}\right)$ \\
\hline $\mathbf{4}$ & Waste & ${ }^{\circ} \mathrm{C}$ & Natural $^{\mathbf{1}}(\mathbf{C})$ \\
\hline $\mathbf{5}$ & Temperature & & $\mathbf{6 , 5 - 8 , 5}$ \\
\hline Chemical & $\%$ & Natural $^{\mathbf{3}}(\mathrm{e})$ \\
\hline $\mathbf{1}$ & pHd & $\mathbf{2 0 0}\left({ }^{\mathbf{r}}\right)$ \\
\hline $\mathbf{2}$ & Salinitye & MPN & \\
\hline Biology & Coliform
\end{tabular}


2.2.2.2 Compatibility Matrix Analysis For Beach Tourism

Matrix analysis of the suitability for use Table suitability travel tour coast beaches as follows:

Table 3 Matrix's compliance To Beach Tourism

\begin{tabular}{|c|c|c|c|c|c|c|}
\hline \multirow[t]{2}{*}{ No. } & \multirow[t]{2}{*}{ Parameter } & \multirow[t]{2}{*}{ Quality } & \multicolumn{4}{|c|}{ Category } \\
\hline & & & score 3 & score 2 & score 1 & score 0 \\
\hline 1 & Beach Type & 0200 & White sand & $\begin{array}{l}\text { White Sand } \\
\text { Reef Mixed } \\
\text { Fractions }\end{array}$ & $\begin{array}{l}\text { Black Sand, } \\
\text { Little Rough }\end{array}$ & $\begin{array}{l}\text { Mud, Gravel, } \\
\text { Rough }\end{array}$ \\
\hline 2 & The width of the beach & 0200 & $>15$ & $10-15$ & $3-<10$ & $<3$ \\
\hline 3 & Base Materials Bodies & 0170 & Sand & Reefs Sandy & Muddy sand & Mud, mud Sandy \\
\hline 4 & Water Depth (m) & $0: 13$ & $0-3$ & $>3-6$ & $>6-10$ & $>10$ \\
\hline 5 & Bodies Brightness (\%) & $0: 13$ & $>80$ & $>50-80$ & $20-50$ & $<20$ \\
\hline 6 & Flow velocity $(\mathrm{cm} / \mathrm{sec})$ & 0080 & $0-17$ & $17-34$ & $34-51$ & $>51$ \\
\hline 7 & The slope of the beach $\left(^{\circ}\right)$ & 0080 & $<10$ & $10-25$ & $>25-45$ & $>45$ \\
\hline 8 & Land Cover Beach & 0010 & $\begin{array}{c}\text { Coconut, Land } \\
\text { Open }\end{array}$ & $\begin{array}{l}\text { Bushes, } \\
\text { thickets, Low } \\
\text { Savana }\end{array}$ & High Thicket & $\begin{array}{c}\text { Mangrove, } \\
\text { Settlement, Harbor }\end{array}$ \\
\hline 9 & biota Dangerous & 0005 & There is no & Sea urchins & $\begin{array}{c}\text { Pig Fur, Fish } \\
\text { Pari }\end{array}$ & $\begin{array}{l}\text { Pig Fur, Fish Pari, } \\
\text { lionfish, shark }\end{array}$ \\
\hline 10 & $\begin{array}{l}\text { Freshwater availability / } \\
\text { Distance Resources } \\
\text { Freshwater }(\mathrm{km})\end{array}$ & 0005 & $<0.5$ & $>0.5-1$ & $>1-2$ & $>2$ \\
\hline
\end{tabular}

Then proceed with the following formula (Yulianda, 2019):

Information :

$$
\sum_{i=1}^{n}(B i x S i)
$$

IKW: Tourism Suitability Index

n: Number Parameter

Bi: Parameter Weights All i

Si: Parameter Score All i

Then the class determination using three classification

$\mathrm{S} 1=$ is in accordance with IKW $>2.5$

$\mathrm{S} 2=$ accordance with IKW $<2.0-<2.5$

S3 = not in accordance with IKW $<1-<2$

S4: Not Available <1

2.2.2.3 Capability Analysis of Tourism Region

Analysis of carrying capacity of tourist areas using the following formula:

$$
D D K=K X \frac{L p}{L t} X \frac{W t}{W p}
$$

Information :

DDK = The carrying capacity of the region DDK

$\mathrm{K}=$ Potential ecological visitors per unit area

$\mathrm{Lp}=$ Area or length of the area that can be utilized

$\mathrm{Lt}=\mathrm{Unit}$ areas for certain categories

$\mathrm{Wt}=$ time allotted by region for tourism activities in one day

$\mathrm{Wp}=$ time spent by a visitor to any Specific activity (Yulianda, 2019)

\subsubsection{SWOT Analysis}

SWOT analysis is done by identifying four things, namely, strengths, weaknesses, opportunities, and threats in Tete by specifying three important points on 4 it and determine strategies that will be run by combining four components SWOT (Rangkuti, 2005)

\section{RESULTS AND DISCUSSION}

\subsection{Water Quality Parameters}

Tete beach water quality parameters such as $\mathrm{pH}$, temperature, salinity, brightness, and coliform are presented in Figure 2 as follows: 


\section{Water Quality Parameters}

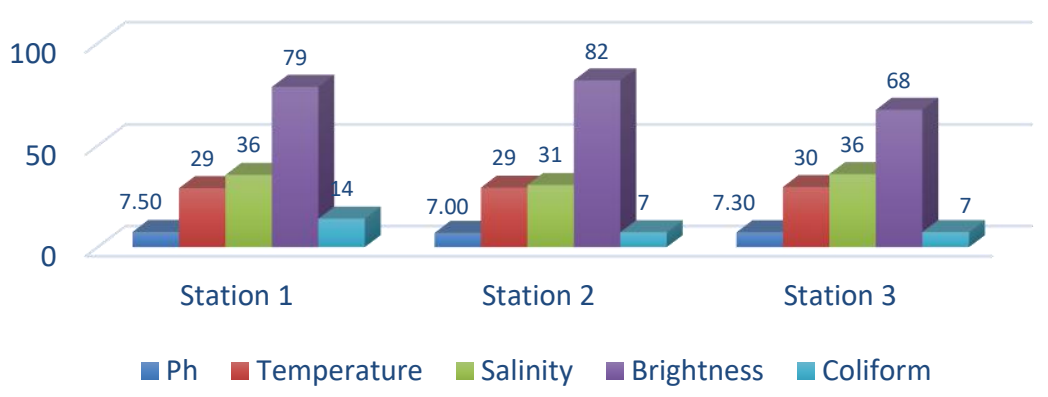

Fig.2: Parameters TeteBeach Water Quality

Based on Figure 2, three stations have the result of significant water parameters and meets the standards set by the Environmental Decree 51 of 2004 to serve as a tourist area, so it is safe for bathing and swimming tourist activity.

\subsection{Compliance Matrix Parameter Beach Tourism}

The suitability of the parameter measurement Beaches Tete is based on 11 parameters referred to in geology and physics aspects of a beach., Following 11 aspects of the parameters presented in Table 4

Table 4 Parameter Conformity Tete Beach Tourism

\begin{tabular}{|c|c|c|c|c|c|c|c|}
\hline \multirow[t]{3}{*}{ Parameter } & \multirow[t]{3}{*}{ Weight (Bi) } & \multicolumn{6}{|c|}{ Station } \\
\hline & & \multirow{2}{*}{$\begin{array}{c}1 \\
\text { Score }(\mathbf{S i})\end{array}$} & \multicolumn{3}{|c|}{2} & \multicolumn{2}{|l|}{3} \\
\hline & & & $\mathbf{N i}$ & Score (Si) & $\mathbf{N i}$ & Score (Si) & $\mathbf{N i}$ \\
\hline Depth (m) & 0125 & 0730 & 0375 & 0820 & 0375 & 0760 & 0375 \\
\hline Beach Type & 0200 & White sand & 0600 & White sand & 0600 & $\begin{array}{c}\text { white sand } \\
\text { mixed rubble }\end{array}$ & 0400 \\
\hline The width of the beach & 0200 & 6,900 & 0200 & 6110 & 0200 & 4,400 & 0200 \\
\hline Basic materials & 0170 & sand & 0510 & Muddysand & 0170 & sandy coral & 0340 \\
\hline Flow velocity (m / s) & 0080 & $0: 03$ & 0240 & $0: 02$ & 0240 & $0: 24$ & 0240 \\
\hline $\begin{array}{l}\text { The slope of the beach } \\
\left({ }^{\circ}\right)\end{array}$ & 0080 & 4 & 0240 & 4 & 0240 & 3 & 0240 \\
\hline Bodies Brightness (\%) & 0125 & 78.7 & 0250 & 81.89 & 0375 & 67.5 & 0250 \\
\hline Land Cover Beach & 0010 & open field & 0030 & open field & 0030 & open field & 0030 \\
\hline $\begin{array}{l}\text { Freshwater availability } \\
(\mathbf{k m})\end{array}$ & 0005 & $400 \mathrm{~m}$ & 0015 & $200 \mathrm{~m}$ & 0015 & $300 \mathrm{~m}$ & 0015 \\
\hline Total number & & & 2,475 & & 2,260 & & 2105 \\
\hline value Compliance & & & 2946 & & 2,690 & & 2,506 \\
\hline Category Suitability & & A Gre & Fit & $\mathrm{A} \mathrm{Gr}$ & & Corresp & \\
\hline
\end{tabular}

Based on Table 4, each station has a tourist suitability index (IKW) different. This can be seen from Table 4 that where stations 1 and 2 have IKW equal to the weight of 2.9 and 2.6, while the station has a weight IKW reached 2.5 , which means that stations 1 and 2 in the category is suitable for conversion to tour, while at station 3 classified accordingly (Yulianda, 2019), although there are differences in the results of IKW,overall a very appropriate location classified coast to serve coastal tourist area.

\subsection{Carrying Capacity of Tourism Region}

Tete beach has a land area of about $\pm 888,000 \mathrm{~m}$, with a variety of tourist activities in it, it makes the necessary calculations Tete beach carrying capacity of tourist areas (DDK) to set activates as well as the number of tourists who can visit (Yulianda, 2019). The following table bearing capacity calculations TeteBeach tourist area 
Table 5. Carrying TeteBeach Tourism Region

\begin{tabular}{clcc}
\hline No. & Tourism type & $\begin{array}{c}\text { The area of land } \\
\left(\mathbf{m}^{\mathbf{2}}\right)\end{array}$ & $\begin{array}{c}\text { Carrying Capacity } \\
\text { of Region / People }\end{array}$ \\
\hline $\mathbf{1}$ & Beach & 24.500 & 69.619 \\
$\mathbf{2}$ & Pool & 19,300 & 34276 \\
$\mathbf{3}$ & Boat & 856.000 & 6,081 \\
$\mathbf{4}$ & Tombolo & 6400.000 & 18186 \\
\hline
\end{tabular}

Based on Table 5, tourist activity beach Tete there are 4 types, namely beaches, swimming, boating and tombolo by land area and carrying capacity vary, based on the calculation, the beach Tete can accommodate \pm 128 people per day, by division 6 activity boat, beaches 69 people, 18 people tombolo and 34 people swimming travel people.

\subsection{Management Strategy Based on SWOT}

Management strategies using swot is the final step after conducting various analyzes, the results of this method are used as an alternative to beach tourism management strategies Tete, the following table using the Tete Coastal management strategy swot:

Table 6. TeteBeach Management Strategy (SWOT)

\begin{tabular}{|c|c|c|}
\hline internal & $\begin{array}{l}\text { Strength }(\mathbf{S}) \\
\text { - } \\
\text { Travel biology and physic } \\
\text { relatively good condition } \\
\text { The relatively strong security } \\
\text { because it is managed by } \\
\text { Indonesian National Armed Forces } \\
\text { - Supporting facilities adequate } \\
\text { travel }\end{array}$ & $\begin{array}{l}\text { Weakness }(\mathbf{W}) \\
\text { - } \quad \text { Access (road) is not good } \\
\text { The distance to the city } \\
\text { farthest travel }(61 \mathrm{~km}) \\
\text { - } \\
\text { Diversity unfavorable } \\
\text { conditions } \\
\text { Within } 1 \text { year } 2 \text { months are se } \\
\text { up as army training schedule }\end{array}$ \\
\hline $\begin{array}{l}\text { Opportunities (O) } \\
\text { - As the land is public } \\
\text { economy income } \\
\text { There is uniqueness } \\
\text { (tombolo) that became Pull } \\
\text { The existence and the } \\
\text { beauty of the beach Tete has } \\
\text { been widely known to the } \\
\text { public about }\end{array}$ & 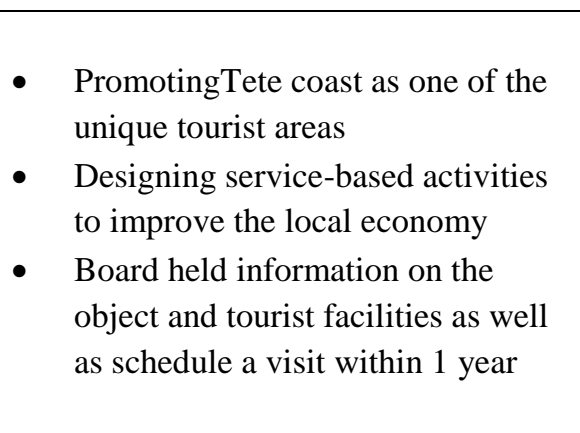 & $\begin{array}{l}\text { Eduwisata about Tantara } \\
\text { training activities in a given } \\
\text { month } \\
\text { - Conducting marine } \\
\text { transportation so that tourists } \\
\text { enjoy the ride } \\
\text { - Holding a beach rides }\end{array}$ \\
\hline $\begin{array}{l}\text { Threats (T) } \\
\text { - There is a conflict between } \\
\text { the government and the } \\
\text { military } \\
\text { - The presence of sand mines } \\
\text { around so disturbing tourist } \\
\text { transport lines } \\
\text { - There is a conflict between } \\
\text { the military and society }\end{array}$ & $\begin{array}{l}\text { - Cooperation between local } \\
\text { government and the military in } \\
\text { travel management } \\
\text { - Give a warning to the perpetrators } \\
\text { of coastal miners to be responsible } \\
\text { for damages access (roads) } \\
\text { - Utilizing the local community in } \\
\text { maintaining cleanliness and } \\
\text { facilities around the beach Tete }\end{array}$ & $\begin{array}{l}\text { - Having the government as an } \\
\text { investor in the form of sea } \\
\text { transport, and TNI as a tour } \\
\text { manager beach. } \\
\text { - Utilizing the public in the } \\
\text { development of coastal } \\
\text { tourism activates } \\
\text { zForming a group tour guide } \\
\text { for tourists visiting during } \\
\text { training by utilizing the } \\
\text { surrounding communities. }\end{array}$ \\
\hline
\end{tabular}

Based on table 6 there are various strategies that need to be done by considering four important aspects, as well as promote the Tete, designing activities based services to the surrounding community, held an information board, education and tour on the training ground Tantara, conduct sea transportation, organized rides beach, giving warning for mining industry, utilizing the services of the public to maintain cleanliness and preservation Tete Beach, as well 
as doing the most important thing is the cooperation between the Indonesian National Armed Forcesas a manager, and calls on the government as an investor and the local community as providers of tourism activities.

\subsection{Conclusion}

\section{CONCLUSION}

TeteBeach has the potential to be a tourist area, which can accommodate about \pm 128 people per day with natural beauty and worthiness owned, as well as adequate facilities to support the convenience of tourists. ss

\subsection{Recommendations}

There should be cooperation between the government, police and the community for the development of management.

\section{REFERENCES}

[1] Buangsampuhi, R., Pingkan, PE, Dan Esli, DT 2019. At the Community-Based Tourism Planning Special Area Turtle Conservation District LamanggoSitaro In the village. Spatial Journal. Vol 6 (2)

[2] central statistical agency. 2019. The number of foreign tourists visiting Indonesia in February 2019 reached 1.27 million visits, Viewed 4 April 2019, https: // Www.Bps.Go.Id/Pressrelease / 2019/04/01/1610 / NumberVisits Wisman -All Indonesia-February-2019-Achieving-127-Million-Kunjungan.Html

[3] Febriansyah, Y and Aldiano, R, A. 2018. Design Menganti Beach Resort in Region Kebumen With Environmental Sustainability Approach. Architectural Studies Program Faculty of Science and Technology University of Technology in Yogyakarta

[4] Law of the Ministry of Environment No. 51. 2004. Marine Water Quality Standards. Main. Jakarta

[5] Lazuardi, I., Peter, S., and Hariyadi. 2013. Analysis of Conformity Bodies For Snorkeling And Diving Tourism At Banana Island North Section of West Lampung District of the North Coast. Journal Of Marine Research. Vol 2 (3)

[6] Marine and Fisheries Ministry. 2018. Https://News.Kkp. Go.Id/Index.Php/10-Tempat-Wisata-Pantai-Di-Indonesia Terindah-Dan-Memiliki-Potensi-Alam-Yang Large /, Diaskes On 27th Month in February 2019.

[7] Rangkuti, F. 2005. Dissecting SWOT Analysis Technique Business Case. PT. GramediaPustaka

[8] Sani, M, Y and Muhadjir, H, S. 2019. Bajo Taka Bonerate: People Around Selayar Island Marine Tourism. Journal Of Tourism And Hospitality Management. Vol 7 (1)

[9] Sulisyati, R., Erny, P., RWF Lies, And Chafid F. 2016. Optimization of Tourism Use Zone

[10] Vitello, R. 2018. Exotic Frog WatuGunungKidul in Yogyakarta. Amburrukmo Yogyakarta Tourism College. Domestic Case Study.

[11] Yahya, M. 2015. Potential As Tete Beach Travel Attractions in Bone County
[12] Yulianda, F. 2019. Ecotourism as an Alternative Maritime Coastal Resource Utilization 